\title{
The Botswana-Namibian Boundary Dispute in the Caprivi: To what extent does Botswana's Arms Procurement Program represent a drift towards Military Confrontation in the Region?
}

\author{
C J B LE ROUX \\ Department of Political Science, University of Zululand
}

\begin{abstract}
The Botswana and Namibian governments are currently involved in a dispute with each other over ownership of the small islands of Kasikili-Sedudu, (Kasikili is the Namibian name for the island) and Situngu in the Caprivi Strip. Like Sedudu, the Namibians also variedly refer to Situngu as Luyondo, Singobeka, Mbala and Zoti. The dispute over Sedudu Island currently serves before the World Court in The Hague, while the dispute over Situngu has been referred to a joint technical committee that has been set up by the two governments.
\end{abstract}

The fear has been expressed that, given the strong national sentiments and heightened emotions surrounding the dispute, the losing side may not accept the World Court's decision on Sedudu Island, which is expected before the end of 1999. Oral submissions started on 15 February ${ }^{1}$ and the court is currently preparing its findings on the matter. Should either of the two applicants refuse to accept the Court's findings Southern Africa could very well be faced with a protracted border war in the region. The dispute over the two islands have been going on since $1991^{2}$ and both Botswana and Namibia's current arms procurement programs have been indirectly linked by some observers to the dispute over the two river islands in the Caprivi Strip.

Botswana is reportedly also not happy with Namibia's plans to pump large quantities of water on a permanent basis from the Okavango River while Namibia, in turn, has stopped short of accusing Botswana of aiding the Caprivi nationalist movement of Mishake Muyongo in his search for independence for the Caprivi from Namibia. Muyongo, like the majority of the 100000 strong Mafwe people in the Caprivi, are Lozi-speaking and shares a common kinship with the Lozi tribes across the border in Zambia. ${ }^{3}$ The secessionist leadership chose Botswana for political asylum in October 1998 when it became known that the Namibian government was about to arrest them. By December 1998 more than 2200 Caprivian secessionists, including some 700 from the Linyanti area alone, had fled from the Caprivi into Botswana to escape possible persecution from the Namibian government. ${ }^{4}$

Other developments that have raised eyebrows and which have been speculated upon in the media, have been the construction of the highly secret military air base by Botswana at 
Molepolele and the close co-operation that allegedly exists between the Botswana Government and the CIA. Some sources claim that the base was constructed with funding from the CIA.

The aim of this article is to examine to what extent the arms procurement programs of Botswana [and more recently also Namibia] can be linked to the island dispute and the other issues that currently bedevils relations between the two countries. Although a fair amount of information is available on the dispute between the two neighbours, this information is largely secondary in nature and often conflicting in content and interpretation because of its contemporary nature. Media reports and the contents of meetings are often contradictory, and as events are constantly changing what is relevant today may be irrelevant tomorrow. Every attempt has been made to be as accurate as possible and to provide reputable sources for the facts contained in this article, yet it is quite possible that some of the facts and figures and their relevance would have changed by the time this article is published. This, unfortunately, is the nature and weakness of contemporary research.

\section{INTRODUCTION}

Botswana and Namibia are currently involved in a dispute with each other over ownership of the small river islands of Kasikili-Sedudu (called Kasikili by the Namibians) and Situngu in the Caprivi Strip. Situngu Island is also variedly referred to as Luyondo, Singobeka, Mbala and Zoti by the Namibians. ${ }^{5}$ The dispute over Sedudu Island currently serves before the International Court of Justice (ICJ) in the Hague after the two governments failed to determine the ownership of the island in 1996. The dispute over Situngu Island has been referred to a joint technical committee that has been set up by the two governments to determine ownership of the island. The decision of the ICJ, which began its hearing of the dispute in February 1999, is expected before the end of the year. ${ }^{6}$ The fear has been expressed that, given the strong national sentiments and heightened emotions surrounding the dispute over the islands, the losing side may not accept the Court's final decision which is expected before the end of 1999. ' Should this come about Southern Africa could face a protracted and destabilizing border war that may embroil other neighbouring countries in the region?

The dispute over the two islands can be traced back to 1991 when Botswana laid claim to Kasikili-Sedudu and responded by stationed troops on the island. When a boundary delimitation committee set up by the two countries failed to determine the ownership of the island, and after some substantial military build-up along the common border between the two neighbouring countries, the dispute was finally referred to the ICJ in 1996. A year later in 1977 Botswana also became embroil with Namibia over a second river island in the Caprivi Strip known as Situngu which it claims also belongs to it. Namibia rejected Botswana's claim. After some strong verbal exchanges and some sabre rattling between the two countries, a meeting was held at Katima Mulilo in January 1998 to help reduce the tension that surrounds the disputed ownership of the island. One of the aims of the meeting was to set up a joint committee to demarcate the disputed boundary at Situngu. ${ }^{8}$ The meeting unfortunately did not achieve very much and in February 1998, it was reported in the press ${ }^{9}$ that the Namibian government had sought the support of President Robert Mugabe of Zimbabwe to help 
convince Botswana to withdraw its troops from the disputed island. ${ }^{10}$ According to the Mail \& Guardian, " the two countries have since adopted in principle an accord, agreeing on a nonmilitary solution to their territorial disputes in the Caprivi. ${ }^{12}$ According to the same source, the accord still had to be adopted and ratified by the two governments. It is not clear whether this has been done since.

In January 1998, it was reported ${ }^{13}$ that an article had appeared in The Windhoek Observer claiming that the NDF has imported 979.8 tons of military equipment through Walvis Bay. The equipment apparently came from Russia and was delivered to one of the country's largest military bases at Grootfontein, north of Windhoek. It was speculated that this latest military import (thereby suggesting that others had preceded it) by the NDF could be the result of the growing tension between Namibia and its neighbour Botswana over the two disputed islands in the Caprivi. ${ }^{14}$

Another issue that has been causing serious tension Botswana and Namibia has been Namibia's decision to pump large quantities of water from the Okavango River, which feeds the ecologically sensitive Okavango Delta. Botswana believes that plans by Namibia to divert large quantities of water from the Okavango near Rundu, has the potential of turning the Okavango Delta into a desert. Some Botswana leaders, such as Tawana Moreni, the Delta's paramount chief, has apparently even suggested that Botswana should buy more planes and bomb the pipeline. ${ }^{15}$

Botswana recognizes the fact that Namibia has a serious shortage of water and that a mechanism in the form of OKACOM, a joint commission set up by Botswana, Namibia and Angola, is there to safeguard against any unilateral interference with the Okavango River, yet it remains fearful that Namibia may unilaterally decide to proceed with its plans to construct the pipeline. Representatives from Owens Corning, an American company with strong business ties to South Africa, visited Windhoek in 1996 in connection with the construction of the proposed pipeline. The pipeline, which is expected to cost about R1-billion, is designed to draw an estimated 20 -million cubic meters of water from the Okavango per annum. ${ }^{16}$

Namibia has made it clear that should Botswana reject the feasibility study on the project, it will have little alternative but to unilaterally proceed with the project and that it would expect the Botswana government to respond to the pipeline project sympathetically. ${ }^{17}$

Whether these and other developments, such as the construction of the highly secret air base at Malepolele, have had any direct bearing on Botswana's accelerated arms purchases since the mid-1990s is difficult to say. Defence experts and political analysts have however speculated that Botswana's arms purchases may have something to do with its ongoing border dispute with Namibia over Kasikili-Sedudu and Situngu in the Caprivi and Namibia's decision to pump water from the Okavango River. ${ }^{18}$ The idea that two of Africa's model countries could go to war over a couple of sandbanks may seem far-fetched, but the United Nations has warned that with freshwater sources in ever greater demand, control over rivers, rather than oil, could spark many of the $21^{\text {st }}$ century's wars. ${ }^{19}$ 


\section{THE BOUNDARY DISPUTE IN THE CAPRIVI STRIP}

In terms of International Law, river boundaries generally follow the centre of a river. In the case of Botswana and Namibia the common border between the two countries in the Caprivi Strip was determined by the Anglo-German Treaty signed in July 1890. The Treaty drew the border between the two countries to run eastwards along the $18^{\text {th }}$ degree south latitude until it reaches the Chobe (some maps refers to it as the Kwando) River, from where it follows the centre of the river until it reaches the Linyanti River. From the Linyanti the border runs along the centre of the river through the southern part of Lake Liambezi and then down the centre of the Chobe to the Zambezi. This Treaty, together with the Anglo-Portuguese Treaty of 1892, forms the common basis of the dispute over Sedudu Island which served before the ICJ earlier this year. In terms of Articlel of the Special Agreement of 15 February 1996, the ICJ was asked to determine the boundary around Kasikili-Sedudu Island and thus the legal status of the island on the basis of the Anglo German Treaty of 1890 and the rules and principles of international law pertaining to such disputes.

According to Botswana the wording in the Anglo-German Treaty of 1890 that is relevant to the dispute, appears in Article III, paragraph 2, which deals with the boundary of the German sphere of influence in South West Africa. Being Anglo-German the Treaty is written in both English and German. The relevant section in German reads as follows: ${ }^{20}$

„ein Linie . . . läuft dann in östlicher Richtung diesem Breitengrade entlang, bis er den Tschobe-Fluss erreicht und setzt sich dann im Thalweg des Hauptlaufes dieses Flusses bis zu dessen Mündung in den Zambese fort, wo sie ihr Ende findet."

In English the corresponding passage reads as follows:

"a line [meaning the line of demarcation of the German sphere of influence] ... runs eastward along that parallel [meaning the 18 parallel] till it reaches the River Chobe; and descends the centre of the main channel of that river to its junction with the Zambesi, where it terminates."

According to Botswana the dispute centers around the meaning of the words "in the centre of the main channel of that river" and "im Thalweg des Hauptlaufes dieses Flusses".

In terms of paragraph 1 of the Vienna Convention on the Law of Treaties, which may be considered as a codification of existing customary international law, "a treaty shall be interpreted in good faith in accordance with the ordinary meaning to be given to the terms of the treaty in their context and in the light of its object and purpose." In line with this Botswana argued that the ordinary meaning of the expression used both in the English and the German text of the Treaty is that the boundary line runs in the main channel or "thalweg" of the Chobe River. ${ }^{21}$ 
Linguistically the word "thalweg' means "the way downward," and can be associated with the deepest channel, it does not necessarily refer to the main channel of a river. It may however refer to the deepest part of the main channel. ${ }^{22}$ Moreover, the treaty-makers in 1890 did not always adopt a consistent choice of location of the boundary along the course of a river which adds to the problem of accurately determining some river boundary such as the Chobe. $^{23}$

\section{KASIKILI-SEDUDU ISLAND}

Kasikili-Sedudu Island, although not the largest, is perhaps the most important of the two islands in dispute. The island is between 3 to 3,5 sq. kilometers in size and is situated in the Chobe River near Kasane. The dispute over the ownership of the island first hit the media headlines in early 1992 when Botswana laid claim to the island following the alleged kidnapping of two British tourists by Namibians on the Chobe side of the island. The BDF, which normally conducts only anti-poaching operation in the region, immediately stepped-up its military presence along the Botswana-Namibian border. According to media reports the situation quickly deteriorated after an exchange of fire between Botswana and Namibian troops and following claims by the Namibian government that the BDF had flown the Botswana flag on the island. The Namibians accused the BDF of taking land through "the barrel of the gun." 24

Namibia's claim to the island is based on the fact that it has been used by them, especially the Masubia of the Caprivi, since 1907 for grazing and fishing purposes and that it has never been used or claimed by people or officials from the old Betchuanaland Protectorate prior to the dispute. ${ }^{25}$

At a meeting held at Kasane in July 1992 and attended by Presidents Sir Ketumile Masire of Botswana and Sam Nujoma of Namibia, and chaired by President Robert Mugabe of Zimbabwe, it was decided that an amicable solution must be found as to the ownership of the disputed islands. It was agreed that a team of six technical experts, three from each country, be set up to determine the border between the two countries. It was further decided that until the matter has been successfully solved both countries should withdraw their troops from Kasikili-Sedudu Island, even those on anti-poaching duties. ${ }^{26}$ Among the experts appointed by Botswana to determine the ownership of Kasikili-Sedudu Island were Professor Ian Brownlie, Chichele Professor of Public and International Law at Oxford University, and the author of the book "African Boundaries"; Mr. Isaac Muzila, the Principal Hydrological Engineer in the Department of Mineral Resources and Water Affairs; and Mr. John Bates, an Independent Surveyor and former Deputy Director of the Department of Surveying and Lands.

The Namibian appointments to the team consisted of the Permanent Secretary in the Ministry of Justice, Dr. Kawana, the Surveyor General, Mr. Reuter, and a Dr. Hungula. ${ }^{27}$

Despite the urgency of the matter, the technical team dragged its feet and it was not until September 1993 that it had its first full meeting. Its second meeting was in Gaborone at 
the beginning of October, where it agreed on the terms of reference. By 1995 however it had become clear that the team was unable to find an acceptable solution to the dispute and in the end Botswana and Namibia agreed that the matter should be referred to the ICJ. Consequently on 29 May 1996 the Governments of the Republic of Botswana and Namibia jointly notified the Registrar of the ICJ that a Special Agreement had been reached between them at Gaborone (Botswana) on 15 February 1996(it came into force on 15 May 1996), in terms of which they have agreed to submit the dispute over the boundary around Kasikili-Sedudu Island and the legal status of the island, to the ICJ.

Under the terms of this Special Agreement the parties asked the Court to determine, on the basis of the Anglo-German Treaty of July 1890, and the rules and principles of international law, the boundary between Namibia and Botswana around Kasikili-Sedudu Island and the legal status of the island, ${ }^{28}$

Although both parties to the dispute have agreed in February 1996 to abide by the decision of the ICJ there has been persistent rumours since then that the losing side may not accept the decision of the ICJ. ${ }^{29}$

Most Batswana believe that the island legally belongs to Botswana and that the ICJ will decide in their favour. They have given full support to Botswana's decision to take the matter to the ICJ. Chief Lopang Kadimo of Kasane village near the island says people in his area have used the island for grazing and farming as long as he can remember and that there can be no doubt that it belongs to Botswana. Other residents of Kasane such as Dikeledi Lesheto, states that while she appreciates the government's efforts to refer the matter for international arbitration there can be no doubt that "Sedudu Island is part of our territory" and is important for the tourism industry.

A spokesman for the office of the then President Masire in Gabarone, Mr. Molosiwa Selepeng, has denied media reports that relations between the two countries have become strained over the island dispute. ${ }^{30}$

Although the tension that surrounded the island dispute had somewhat dissipated since the issue was referred to the ICJ in 1996, much of the current tension between the two neighbouring countries emanates from the dispute over Situngu, a second river island in the Caprivi.

\section{SITUNGU ISLAND}

Historically, the dispute over the marshy island of Situngu, which is about $14 \times 7$ kilometers in size and situated in the Linyanti rivers some 270 kilometers west of Sedudu Island, began in October 1997, when members of the BDF discovered ploughed fields on the southern side of the island which they claimed is on their side of the border. Situngu, also called Singobeka, has apparently been used by Namibian farmers for a very long time without any apparent objection from the Botswana government. Most of these Namibian farmers are absentee landlords. They cross the river during the day to check on their crops, which 
compete with the weeds on the island for its fertile soil. ${ }^{31}$ The island is about an hour's flying time west from the border town of Kasane. The dispute over the island came to a head in January 1998 when a high-level Namibian delegation, that included the Minister of Defence, Mr. Erikki Nghimtina, and under escort of a Namibian Defence Force motorised unit; accompanied by two helicopters, was prevented by the BDF from crossing onto the Island. ${ }^{32}$

According to media reports the BDF told Namibian villagers at Singobeka village in the Linyanti district in October 1997 to leave the area as it belonged to Botswana. In an attempt to defuse the situation an emergency meeting was held later in the same month between representatives from both Botswana and Namibia at Kasane, where it was resolved that the matter should be referred to the traditional leaders of the area, Mafwe Chief Boniface Mamili and his unnamed counterpart from Botswana. ${ }^{33}$ Chief Mamili was one of the leaders of the Caprivi secessionist movement that fled into Botswana in October 1998.

The Kasane meeting was followed by a further meeting held at Katima Mulilo in November 1997. According to media reports some villagers in the Singobeka region believed that Botswana's claims to Situngu Island was little more than an excuse by the BDF "to test their new military hardware," something the BDF has denied. ${ }^{34}$ It was also alleged in the Namibian press in January 1998 that a Namibian army general had visited Situngu Island and proclaimed that the disputed island indeed belonged to Botswana. The Namibian general was apparently flown to the island in a BDF helicopter. ${ }^{35}$

Since these developments in 1997 the BDF has erected a two-tent ${ }^{36}$ camp on the island and instructed its troops to stop all Namibians, even senior government officials, from entering the island. ${ }^{37} \mathrm{~A}$ subsequent statement released by the Botswana government stated that it was "gravely concerned" at the attempt by Namibian troops to cross illegally onto Botswana territory. ${ }^{38}$ Botswana event went so far as to accuse the Namibian government of misleading the public and creating tension between the two countries over the Situngu Island dispute.

Namibian villagers from the nearby Singobeka village have apparently complained to the Namibian Government that the BDF soldiers stationed on the island have harvested and eaten their crops and have harassed them if they could not produce passports to enter the island. $^{39}$

The Botswana government has defended the actions of the BDF as being part of its normal task to patrol the borders along the Botswana side of the Linyanti and Chobe rivers, and to curb any illegal cross-border activities, including game poaching, and anyone encroaching onto Botswana territory through activities such as "settlement, ploughing, grazing and the rearing of live-stock., ${ }^{40}$

These developments came despite a meeting of all parties at the end of 1996 at which it was decided that the Namibian villagers, who have farmed on the island for years, would be allowed access to the island to harvest and tend to their crops. 
In an attempt to find a solution to the island dispute Victor Muititi, a spokesperson for an unnamed Lozi headman in the Caprivi, visited the former Commander of the South African Defence Force (SADF), General Constand Viljoen in Pretoria towards the end of 1997 to discuss, inter alia, Botswana's sole claims to Situngu Island; that country's military build-up in the region; and Namibia's apparent failure to deal with the situation. Viljoen was approached by Muititi, because the headman he represented, knew Viljoen from the days of the "bush war" in Angola and he was sufficiently impressed by him to seek his advice on the island dispute. ${ }^{41}$

It was reported in the Namibian press in February 1998 that the Namibian government was "setting up a diplomatic front" against Botswana's ongoing occupation of the disputed Situngu Island and from which its troops are refusing to move. ${ }^{42}$ The Namibian President, Sam Nujoma, apparently traveled to Pretoria on 29 January 1998 to consult with President Nelson Mandela, the Chairperson of the Southern African Development Community (SADC), over the dispute. President Nujoma also met with President Robert Mugabe of Zimbabwe prior to his visit with President Mandela. President Nujoma informed the media on his return to Windhoek that in his consultations with President Mandela on the dispute he had raised the possibility of the president acting as mediator in the matter. ${ }^{43}$

Despite the ongoing talks between the two countries over Situngu and a joint decision by both countries to set up a joint technical body ${ }^{44}$ to demarcate the disputed boundary between them, Botswana has flatly refused to remove its troops from the island. It remains adamant that the island belongs to it and that Namibia is violating the colonial boundaries drawn during the "Scramble for Africa" and accepted by Organization of African Unity $(\mathrm{OAU})$ at its foundation in 1963. It has, however, agreed to a compromise that the Namibians who have planted crops on the island could continue working their fields and crops until harvest time. ${ }^{45}$ Thereafter, presumably, they must leave the island.

According to Botswana, the border between itself and Namibia is clearly demarcated in terms of the Anglo-German Treaty of 1890, but that the Namibians refuse to accept this. They, the Namibian, prefer to base their claims on the stories and accounts of locals in the region, who claim the boundary is a stream four kilometers north of the Linyanti River. According to Major-General M. Fisher, the Deputy Commander of the BDF, this river boundary that the Namibian tribesmen refers to is little more than a dry tributary of the Linyanti River and not the main channel as they claim. The Namibians dispute this.

In February 1998 it was reported that Francis Sizimbo, a Namibian member of the opposition Democratic Turnhalle Alliance (DTA) party, whose constituency encompasses the area around Situngu Island, has stated that he does not believe the initiative to resolve the dispute will be successful due to a conflict of interest. ${ }^{46}$ Both parties, he said, have conflicting views on where the actual border should be. To us, he said, the Botswana troops are three kilometers inside Namibian territory. Botswana on the other hand is creating the impression that Situngu is located in the Linyanti River, which is not the case, he said. The disputed territory, which he described as "much bigger than Kasikili", is located between the Linyanti River and a stream called the Sampisi. ${ }^{47}$ Many believe the current demarcation commission 
will be as unsuccessful as was the joint commission, established by the Botswana and Namibian governments in the early 1990 s, to determine ownership of Kasikili-Sedudu Island.

In May 1998 it was reported in the South African and Namibian press that an "accord" has been reached by Botswana and Namibia representatives that called for a nonmilitary solution to the boundary dispute between the two countries. According to the report the accord, which still had to be ratified by the two governments, represented the strongest sign yet that the two neighbours have reached an agreement to settle their disputes through diplomatic means. ${ }^{48}$

\section{ATTEMPTS BY THE NAMIBIAN AND BOTSWANA CHURCHES TO END THE DISPUTE}

If anyone still had doubts about the seriousness of the border dispute, this was dispelled by the announcement in April 1998 that Church leaders from the Namibian Council of Churches $(\mathrm{CCN})$ and the Botswana Christian Council $(\mathrm{BCC})$ have met at the Kempton Park Conference Centre in Johannesburg to discuss the mounting tension brought about by the border dispute between the two countries, and to see if a way could not be found to help

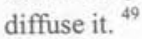

In a combined communiqué released by the $\mathrm{CCN}$ and the $\mathrm{BCC}$ in April, it was stated that it was "... recognized that the burden of responsibility for peace making and development of good neighbourliness rests with member churches of both Councils....". ${ }^{30}$ A month earlier the $\mathrm{CCN}$, at its AGM held in Windhoek, urged both governments to find a peaceful settlement to the dispute between them. ${ }^{51}$

\section{BOTSWANA'S ARMS PURCHASES}

In June 1996, some three months after Botswana and Namibia referred their dispute over Kasikili-Sedudu to the ICJ, it was reported in the South African media that Botswana was negotiating for the purchase of 13 US-built F-5 Fighter bombers from Canada. ${ }^{52}$ The cost of the purchase was reported to be in the region of US\$ 50 million. The deal, which was confirmed by the Canadian High Commissioner in Pretoria in June $1998,{ }^{53}$ came hard on the heels of an earlier reported deal in January 1996, in which it was reported that the BDF was negotiating with the Netherlands for the purchase of 50 second-hand German Leopard 2 main battle tanks. Although these tanks were second-hand, they were more modern and more advanced than the current South African Centurion-Olifant main battle tank. The BDF was apparently also negotiating for the purchase of 36 British Scorpion tanks, some 200 troop transport carriers, $12105 \mathrm{~mm}$ filed guns from Britain and a battery of $155 \mathrm{~mm}$ medium range artillery pieces from Israel at the time. ${ }^{54}$ The total cost of these weapons was estimated to be in the region of US\$ 63 million (R315 million). ${ }^{55}$ According to the London-based International Institute for Strategic Studies (IISS), Botswana spent about P415 million (about R550 million) on Defence in 1993. This amount increased to P615 million (about R820 million) in 1994 and to P625 million (about R833) in $1995 .^{56}$ These figures represented a substantial increase over the P243.5 million allocated to the BDF in 1989/90. ${ }^{57}$ Botswana's 
defence budget currently (1998/99) represents between 7 and 8 per cent of total government expenditure. $^{58}$

Botswana has apparently also purchased a quantity of infantry equipment from the Netheriands as well as several river patrol boats. ${ }^{59}$ It was subsequently reported that Germany scuttled the deal for the Leopard 2 tanks from the Netherlands on request from the Namibians. Botswana in its determination to equip the BDF with tanks then turned its attention to Austria. According to press reports Austria agreed to sell 32 Gepard (Cheetah) anti-aircraft versions of the Leopard 2 tank to Botswana until Germany again intervened to stop the sale of these vehicles Botswana. ${ }^{60}$ Before this sale was scuttled it was reported in the press that the Botswana parliament had approved an amount of P10 million as a down payment for the tanks in March 1997. ${ }^{61}$ According to the authoritative Jane's Defence Weekly, Botswana has since placed a new order, this time for 20 Austrian-built Steyr-Daimler-Puch SK 105 light tanks/destroyers, with an option to purchase a further 30. The order for these Austrian designed and built tanks has apparently been approved by the Austrian Government and the firm manufacturing the tanks is currently in the process of filling Botswana's order for the first 20 tanks. ${ }^{62}$ It is not clear when these tanks will be delivered to Botswana but they will provide the BDF with the most up to-date vehicles of their kind.

Germany has apparently also scuttled an earlier attempt by Botswana to purchase second hand Leopard 2 tanks from Belgium. According to an unnamed German Foreign Affairs official, Germany has a standing agreement with European countries where its leopard tanks are produced under license that prohibits these countries from selling any Leopard tanks or their derivatives to a third party. ${ }^{63}$

The same unnamed German official apparently also told The Namibian that he found Botswana's rationale for wanting tanks namely, to arm itself on the grounds of instability in Southern Africa and for cross-border poaching, rather ridiculous. He suggested that jeeps and light trucks would be more suitable poaching activities than tanks. ${ }^{64}$

Botswana's increased military expenditure was first highlighted at a meeting of the South African Development Community (SADC) held in Zimbabwe in August 1996. At this meeting it was pointed out that, while the destruction of apartheid has removed the greatest destabilizing factor in Southern Africa, other factors, such as the growing tension between Namibia and Botswana over the Caprivi islands, and Botswana's massive expenditure on arms have the potential to create instability in the region. ${ }^{65}$ Although attempts have been made by the two countries to reduce the growing tension between them the relationship between them has remained tense, especially following the recent secessionist attempt in the Caprivi in October 1998, and the growing anticipation that surrounds the verdict of the ICJ over the ownership of Kasikili-Sedudu Island which is expected towards the end of 1999.

\section{THE AIR-BASE AT MOLEPOLELE ${ }^{66}$}

In 1992 it was reported in a well informed British publication on Africa that the Botswana government, with the aid of the United States, was in the process of constructing a 
massive but highly secret air-base near Molepolele (also known as Mapharangwane). France apparently provided P1 000 million for the construction of the new air base, with the balance of the cost of constructing the air base coming from the Botswana government. The project was known as Project Eagle. ${ }^{67}$

The air base was scheduled for completion in 1994/95and consists of three sites. The first and main site is about 35 kilometers from the small town of Molepolele and about 75 kilometers north west of the capital, Gaborone. The second site is at Chobe in the far north near the border with Zambia and Zimbabwe. The third site is in the northwest, in the region of the Okavango delta and the Caprivi Strip, which forms the border between Namibia, Botswana and Angola.

According to the Botswana Minister of Foreign Affairs, Mompati Merafhe, who is also a former BDF Commander, the new air base housed the most basic of facilities and infrastructure needed to develop the air-wing of the BDF.

Some observers have speculated that the arms purchases were intended as a sop to prevent Lieutenant-General Ian Khama, the then Commander-in-Chief of the BDF, from "dabbling in civilian politics. ${ }^{68}$ Others have suggested that Lieutenant-General Khama has been the main driving force behind Botswana's desire for an improved and more sophisticated defence force. ${ }^{69}$ Lieutenant-General Khama however resigned from the BDF in 1997 to take up the deputy presidency. ${ }^{70}$ Lieutenant-General General Khama at the time has denied claims that Botswana was going overboard in arming itself, or that it was out of step with the new spirit of peace and development in Southern Africa. As far as Botswana was concerned, he claimed, it was important for the country to have a defence force to deter potential threats. $\mathrm{He}$ went on to state that "....As we develop our force, it must remain affordable. Unlike other military forces, we did not inherit anything from the (British) colonial administration. We started ... from scratch. We had nothing and we developed our force to what it is today." "Of course, this does not entirely explain Botswana's need for heavy tanks to curtail poaching activities along its border with Namibia.

The new air-base, which is much larger than Gabarone's Sir Seretse Khama International Airport, was constructed by a consortium consisting of France's Spie-Batignolles and South Africa's LTA which acted as the main sub-contractor. LTA is the main construction arm of Anglo-American. ${ }^{72}$ Although France has been identified as the major financier for the construction of the air base it has also been rumoured that the Botswana government also obtained money and equipment from the CIA for the project. Unfortunately, there are no hard and fast facts to substantiate this rumour. What is true is the fact that the Americans is known to view the emerging markets of Africa and Southern Africa in particular, as an important destinations for its manufactured goods, including its military goods. ${ }^{73}$ This point of view was partially born out by President Bill Clinton's high power visit to Africa and Southern Africa in 1997 and his emphasis on the need for America to step-up its trade with Africa and his government's active support for i . e "African Renaissance." 
Washington's support and interest in Botswana also appears to be based on its growing concern over the high levels of crime in South Africa that may negatively impact on the country's socio-political and economic future. The United States, and it is supported in this by Israel, appear concerned about South Africa's growing friendship with some of America and Israel's traditional "enemies" in the Middle East and North Africa. Their concern was strengthened in April 1998 when it was reported that the South African Minister of Justice, Dullah Omar, and Constitutional Affairs Minister, Valli Moosa, met with the Hamas spiritual leader, Sheik Ahmed Yassin, while on an official visit to Saudi Arabia. ${ }^{74}$ The meeting was condemned by the South African Board of Jewish Deputies (SAJBD) and the South African Union of Jewish Students (SAUJS) who expressed their shock and anger over the meeting. In a statement released, the national director of the SAJBD made it clear that the Jewish community in South Africa consider it incomprehensible that such a meeting took place, given the dire warning which Hamas leaders issued earlier in the month in which they vowed to take revenge against Jewish targets world-wide. ${ }^{75}$

But the US and Israel intelligence agencies are not the only foreign agencies that are interested in developments in South Africa and the country's growing ties to the north of the continent and the Middle East. Since the Democratic elections of 1994, there has been a proliferation of interest by foreign intelligence agencies in South Africa. The CIA alone is known to have closed down several of its stations in favour of a greater concentration of staff and operations in Southern Africa. ${ }^{76}$ The CIA apparently began to show an interest in Botswana, after it lost its major eavesdropping facility in Liberia during the 1989 civil war there. It needed a new and politically stable country from where it could conduct its spying operations and Botswana seemed the obvious choice since South Africa was then in the process of transforming itself from a ruling oligarchy to a fully-fledged democracy. ${ }^{77}$

The CIA's new eaves-dropping facility in Botswana is apparently part of the new and more powerful Voice of America (VOA) relay station at Selebi-Pikwe. ${ }^{78}$ The new station was activated at the beginning of 1992 . With the aid of the Botswana facility and in conjunction with an existing but smaller eavesdropping facility in Mbabane, Swaziland, ${ }^{79}$ the CIA is capable of closely monitoring events in Southern and Central Africa. Mr. Mike Louw, the then Director-General of South Africa's National Intelligence Service, predicted in June 1996 that the CIA was probably going to use South Africa as a major base for spying on the African continent. ${ }^{80}$ Information has it that this is now indeed the case. ${ }^{81}$

The growing co-operation between the US and Botswana was clearly revealed in January 1992 when the USAF held combined field exercises with the BDF for several days. The joint manoeuver code named 'Operation Silver Eagle' represented one of the largest US operations ever seen in Sub-Saharan Africa. Historically, the BDF was created in 1977 in direct reaction to the Rhodesian bush war. The BDF, which is about 8000 to 10000 men strong, is rather insignificant if compared to the South African National Defence Force's (SANDF) approximately 100000 men and the Zimbabwean Defence Force (ZDF) of about 40 000 men. The Zimbabwean Defence Ministry stated in June 1996 that Zimbabwe does not feel threatened by Botswana's arms purchases and that the two countries have an excellent 
relationship with each other. It later also told the Zimbabwe Inter-Africa News Agency (ZIANA), that Zimbabwe was satisfied that Botswana was buying the arms for self-defence. ${ }^{82}$

Nonetheless, Botswana's reported intention to purchase sophisticated military hardware and to increase the size of its defence force has been greeted with trepidation by Namibia who has expressed fear of the possibility of an arms race developing in Southern Africa. The Namibian Foreign minister, Theo-Ben Gurirab, has labeled Botswana's arms purchases as 'provocative and unnecessary.' "The last thing, he stated, "we [should] be spending money on now is military equipment, particularly sophisticated equipment. We want to appeal to the friends of Southern Africa not to do anything to escalate an arms race and to resist the seduction of the military-industrial complex. We're looking for regional reconstruction and development." 83

Botswana's explanation that it needs the weapons to "...help with anti-poaching and border-control efforts" $\$ 4$ has done little to settle Namibia's concerns about Botswana's real intention behind its accelerated arms purchases.

Dr Jakkie Potgieter of the Institute for Security Studies in Midrand has argued that the military build-up in Botswana does not reflect any obvious external threat facing the country. The dismantling of South Africa's apartheid system, he points out, has led to a dramatic reduction in tension in the region. He went on to say that even if Botswana did face a conflict with any of its neighbours in the region it is doubtful whether the new equipment would be of much use. ${ }^{85}$ According to Dr. Potgieter, buying tanks is one thing, but keeping them operational is quite another. None of the reported arms deals, he points out, seems to include armoured recovery vehicles or tank transporters or any other back-up equipment needed to maintain such modern and sophisticated weapons. He went on to state that, given the harshness of the environment they would be operating in - the Kalahari Desert - these vehicles will experience huge wear and tear just moving them around. The same applies to the supersonic jet fighters purchased by Botswana. These aircraft such as the ex-Canadian F-5s presents major problems for small defence forces to use properly, he stated. Botswana's second-biggest neighbour, Zimbabwe, he pointed out, learned this latter point to its embarrassment in May 1998 when a flight of its recently acquired MiG 23 fighters failed to show up for a fly-past of the annual trade fair at Bulawayo. They apparently missed the nation's second city. ${ }^{86}$

It has also been pointed out that it would cost the Botswana government about USS 50 million (about R230 million) to train 13 pilots for its new F-5 fighters and that the BDF would have to spend an equivalent amount annually in maintenance and fuel alone to keep these pilots flight-ready. ${ }^{87}$ Before the arrival of the F-5s the BDF's air wing consisted of only a few planes, some of which were third-hand reconditioned jets purchased from Saudi Arabia many years ago. The BDF also possesses some helicopters and transport aircraft.

Since the news on Botswana's proposed arms deal broke in the press in June 1996 the US, which now controls some 52 per cent of the world arms market as compared to only 25 per cent in 1987, has been called upon to reduce its global arms sales. An advisory panel, 
appointed by President Clinton, has warned that the $\$ 22$-billion global trade in increasingly sophisticated conventional arms of which the US holds 52 per cent, seriously threatens to undermine the security of the United States and its friends but in particular Israel. It has called on Washington and its allies to exercise more restraint in selling such weaponry to other countries. ${ }^{88}$

The panel noted that while some arms sales to friendly regimes such as Israel, Egypt and Saudi Arabia can add to US security, it warned that modern arms "have in some cases attained degrees of military effectiveness, (previously) associated only with nuclear weapons" ${ }^{89}$ and expressed particular concern about the risks of selling to unstable regimes in Asia and the Persian Gulf. No mention was made of Africa.

The significantly important role that the US plays in the international arms theatre is borne out by the fact that its share of the global arms market is expected to increase to about 60 per cent by the end of this decade. This represents a phenomenal increase if one takes into account that the global arms market has shrunk by more than 50 percent since the end of the Cold War.

\section{CONCLUSION}

At the onset of this paper the question was asked as to whether Botswana and Namibia may be drifting towards a possible border confrontation over the islands of KasikiliSedudu and Situngu in the Caprivi Strip and whether this dispute may have any bearing on Botswana's accelerated arms purchases since the early 1990s. There is unfortunately no simple answer to this question. Although relations between the two countries over the islands appears to be tense and it has been claimed in the media that there appears to be a link between Botswana (and lately also Namibia's) arms purchases to the dispute, both countries have denied these claims and have repeatedly stated that they prefer to settle their differences through diplomatic means rather than war. In May 1998, it was reported that the Namibia and Botswana governments have signed an accord, agreeing to find a non-military solution to the territorial dispute between them. ${ }^{90}$ For the time being thus, or at least until the findings of the ICJ on the Kasikili-Sedudu Island dispute is known later this year, one has to accept that the two countries are seriously seeking a diplomatic solution to their boundary problems as well as to some of the other areas of dispute. ${ }^{91}$

Nonetheless, one remains acutely aware of the underlying tension that exists between the two countries. There not only appears to be little hope that the two neighbours will find an amicable solution to their dispute over Situngu Island but the issue over Namibia's decision to construct a pipeline from the Okavango to Windhoek to provide the city with fresh water remains problematic for Botswana. This ambitious scheme has met with strong opposition from the Botswana government since it was first announced in 1996. The decision by Namibia to proceed with its plans to start pumping water from the Okavango around 2003 remains hugely unpopular with the people of Botswana who fear that it will destroy the Okavango delta and with it the economy centered on it. This was made quite clear at a meeting of the Botswana-based Okavango Liaison Group in June 1998 when Wanga Moremi, 
a resident from Ngarenge, stated that they, the Batswana people, depend on the delta for almost everything and that without it they would have to move or face death. ${ }^{92}$

Although both governments have indicated that they will abide by the decision of the ICJ expected later this year, some observers are of the opinion that the losing side may eventually be persuaded by growing political/national sentiment, to reject the court's decision. Should this happen the possibility exists that Botswana and Namibia may follow the path of Eritrea and Ethiopia in settling their difference through arms. The reported arms purchase by Namibia in 1998 is seen by some observers as having a direct link to the island and Okavango dispute.

Botswana's political future is closely linked with its socio-economic future which in turn depends to a large degree on uninterrupted supply of fresh water and the future development of the Okavango region for tourism. Although Botswana is rich in diamonds, which accounts for almost 80 percent of the country's exports, as well as in other base minerals, it needs a secure and constant supply of water to develop its economic resources in order to meet the demands that are currently being made on the country by rising unemployment and a rapidly increasing population. In order to create more jobs, Botswana will have to move away from its dependence on diamond exports. Like most countries in Southern Africa, Botswana has seen a steady rise in unemployment, crime, and other social ills since the early 1990s. The country's employment situation has deteriorated to such an extent that increasing numbers of graduates are now unable to find work. ${ }^{93}$ In 1994 , the United Nations' Development Programme (UNDP) rated Botswana as the country with the most skewed income distribution in the world and that the gulf between rich and poor is widening. ${ }^{94}$ All this has serious political implications for the future of the ruling Botswana Democratic Party (BDP).

Although some observers have argued that the current boundary dispute between Botswana and Namibia are little more than a storm in a tea cup others believe the dispute has the potential to quickly develop into open confrontation and in the process suck neighbouring SADC countries into the conflict. Africa has a long history of bloody boundary conflicts that in most instances have proved impossible to solve. Only time will tell whether Botswana and Namibia will abide by the decision of the ICJ or whether they will seek a military solution to their problems.

\footnotetext{
ANB-BIA Supplement, N0. 358 - 15/12/1998, http:/www.peacelink.it/anb-bia/nr358/e03.html.

2 In its presentation before the World Court in February 1999 Namibia argued that BOTSWANA'S deployment of Botswana Defence Force (BDF) soldiers to occupy Namibia's Kasikili-Sedudu Island in 1991 constituted aggression and a unilateral use of force to change the Island's status quo. It was, Namibia's Permanent Secretary of Justice Dr Albert Kawana told the International Court of Justice (ICJ) in the Hague during his opening arguments on the Kasikili-Sedudu Island dispute in "contravention of international law, the United Nations Charter, the Organisation of African Unity (OAU) resolution on colonial boundaries, established diplomatic procedures, and Botswana's own professed foreign policy objectives," Kawana told the court that Botswana was supposed to address the problem through existing agreements between the two
} 
countries that included. among others, the Protocol of Understanding on Defence and Security, which led to the establishment of the Namibia-Botswana Joint Commission on Defence and Security in 1990. He went on to say that the Joint Commission held its first meeting in Windhoek on November 151990 and among the issues that the commission agreed to pay attention to included poaching, "the implementation of joint mechanisms aimed at eradicating criminal activities along the common border, free access to common rivers and the avoidance of cross-border shooting incidents." Kawana said the Namibian Government was surprised that Botswana failed to mention the Kasikili-Sedudu dispute to the Namibian Govemment during that Joint Commission meeting in Windhoek. He reiterated that Namibia believed that the status of Kasikili-Sedudu Island was determined on July 1 1890, as confirmed by the subsequent conduct of the parties to the 1890 Anglo-German Treaty. "Kasikili Island has always been regarded as part of Namibia, and therefore Botswana should not disturb this state of affairs more than 100 years after the conclusion of the 1890 Anglo-German Treaty." Kawana stressed. In terms of the special agreement filed with the International Court of Justice, the two countries have asked the court to determine, on the basis of the Anglo-German Treaty of July 1 1890 and the rules and principles of international law, the boundary between Namibia and Botswana around the Kasikili-Sedudu Island and the legal status of the Island. The Namibian team at the ICJ in The Hague is composed of Namibia's Ministry of Justice Permanent Secretary Dr Kawana as Agent, Namibia's Ambassador to the European Union Dr Zedekia Ngavirue as co-agent, with assistance from 14 Namibian and renowned international legal experts. Botswana's team comprises Botswana deputy AttomeyGeneral Abednego Tafa as Agent, the Permanent Secretary for Political Affairs in the Office of the President, Molosiwa Selepeng as co-agent, and 14 Botswana and international legal experts. The case is being heard by a panel of 15 judges. The two countries earlier pledged that they would accept and respect the outcome of the ICJ. The Namibian, 18 February 1999, http://www.namibian.com.na/

ANB-BIA Supplement No.358, 15 December 1998; Online edition, pp.1-2, Die Republikein, Windhoek, 16 Desember 1998.

The Namibian (Windhoek), 17 December 1998, Die Republikein (Windhoek), 16 Desember 1998.

5 The Namibian (Windhoek) No II February 1998, Online edition.

6 ANB-BIA Supplement, No. 358 - 15/12/1998, http://www.peacelink.it/anb-bia/nr358/e03.html

7 See The Namibian (Windhoek), 7 April 1998, Online edition \& International Court of Justice, Press Communiqué, 98/06, 27 February 1998. pp. 1-2.

8 Namibia News Online (1), 29 January 1998, COMPLIMENTARY FIRST EDITION http://namibia news online (1) $29 / 1 / 98 / \mathrm{html}$.

9 Ibid.

10 The Namibian (Windhoek), 22 October 1997, 14 November 1997, 2-3 February 1998.

11 Mail \& Guardian, 7 May 1998, Online Edition, http:/Mail\&Guadian. Com/news/html/

12 Namibia News Online, 9 June 1998.

13 Namibia News Online (1), 29 January 1998, COMPLIMENTARY FIRST EDITION http:/namibia news online (1) 29/1/98/html.

14 Namibia News Online (1), 29 January 1998. COMPLIMENTARY FIRST EDITION. http://namibia news online(1)29/1/98/html

15 The Mail \& Guardian (Johannesburg, 29 November - 5 December 1996

16 Ibid.

17 The Mail and Guardian (Johannesburg), 6-10 December 1996

18 World News Online edition, The Sydney Moming Herald (Sydney), 11 July 1998.

19 Ibid

20 Tbid.

21 "Talweg" is a term of German origin first used by boatmen on the River Rhine. Because of its frequent use in inter-State treaties which the political division of Africa has produced during the last 25 years, the term 'Talweg', which in many cases is identical with the term 'deepest channel', has acquired citizenship in most civilised languages. Most of them are lacking an expression as short and precise as this term." (Deutsche Kolonial-Lexikon, III (1920), p. 454; B BAD No, 7. The 
International Court of Justice, Public sitting held on Thursday 25 February 1999 in the case concerning Kasikili-Sedudu Island (Botswana) VERBATIM RECORD CR 99/1, p.8

The International Court of Justice, Public sitting held on Thursday 25 February 1999 in the case concerning KasikiliSedudu Island (Botswana) VERBATIM RECORD CR 99/1, pp. $8-10$. Ibid,p.5. Africa Research Bulletin, 1-31 May 1992, p. 10565A

Dikarabo Ramadubu, Botswana Boundary Dispute, Pan African News Agency (PANA), Online Edition, 4 November 1993 International Court of Justice, Press Communiqué, 98/29, 1 October 1998.

The Electronic Mail \& Guardian (Johannesburg), 7 May 1998; The Namibian, 7 May 1998, Namibian News Online, No. 7 , 21 May 1998 \& 9 June 1998.

62 World News Online Edition. The Sydney Moming Herald (Sydney). 11 July 1998. Jane's Defense Weekly, London, June 1998. Online edition.

63 Ibid. 
64 Ibid

65 Elliot Mahende: SADC Prepares to Handle trouble Spots. Pan African News Agency Report, 23 August 1996. Information taken from the Internet.

66 The Molepolele air base in Botswana was perceived during the mid-1980s as a result of the then South African Defence Force's (SADF) incursions into that country. Although relations and co-operation between Botswana and the US have always been good these were strengthen after the SADF raid on the Capital Gaborone in 1985. In December of that year Senior US military officials were sent to Botswana to discuss security and presumably combined operations between the two nations. Additional evidence of the growing ties between Botswana and the US can also be found in the completion of a huge new US embassy in Gaborone in 1990 as well as in the size of the US Peace Corps contingent in the country. At 200 members strong it is the largest presence per capita in the world. Africa Confidential, Vol. 33, No. 3, 7 February 1992, p.5.

67 Africa Research Bulletin, 1-31 January 1992, p. 10435.

68 World News, The Sydney Moming Herald, 11 July 1998.

69 Africa Confidential, Vol.33, No.3, 7 January 1992, p.4.

70 World News, The Sydney Moming Herald, 11 July 1998.

71 Pan African News Agency, 21 February 1996.

72 Africa Confidential, Vol. 33, No. 3, 7 February 1992, p.5. Africa Research Bulletin, Jan 1992, p. 10435

73 Ibid.

74 The Daily News, 22 April 1998

75 Ibid.

76 Africa Confidential, Vol. 35, No.21, 21 October 1994, p. 6.

77 Confidential sources

78 Africa Confidential, Vol.33, No.3, 7 February 1992,p.5

79 Confidential intelligence sources.

80 The Daily News (Durban) 28 June 1996.

81 Confidential Source

82 Pan African News Agency, 21 June 1996, Zimbabwe Says Botswana Arms Procurement No Threat. Taken from the Internet.

83 The Sunday Tribune (Durban), 16 July 1996.

84 Sunday Tribune(Durban), 16 July 1996

85 The Sydney Morning Herald, 11 July 1998.

86 Ibid.

87 Ibid.

88 The Daily News (Durban), 26 June 1996

89 Ibid.

90 The Namibian, 7 May 1998, Namibia News online, Nr. 7, 21 May 1998.

91 Namibia News Online 16 march 1999

92 Electronic Mail \& Guardian, Johannesburg, 5 February 1998.

93 The Daily News (Durban), 28 September 1994.

94 Weckly Mail \& Guardian.14-20 October 1994. 